\title{
VALIDATION OF INTERSECTION ABSORPTION SPECTRUM FOR SIMULTANEOUS DETERMINATION OF BETAMETHASONE VALERATE AND NEOMYCIN SULFATE IN CREAM
}

\author{
Muchlisyam Bachri ${ }^{1, *}$, Julia Reveny ${ }^{2}$, Yade Metri Permata ${ }^{1}$ \\ and C. E. A. Situmorang ${ }^{1}$ \\ ${ }^{1}$ Chemistry Department, Faculty of Pharmacy, Universitas Sumatera Utara, \\ Padang Bulan, Medan, Indonesia. \\ ${ }^{2}$ Technologie Department, Faculty of Pharmacy, Universitas Sumatera Utara, \\ Padang Bulan, Medan, Indonesia. \\ *E-mail: muchlisyam@usu.ac.id
}

\begin{abstract}
Betamethasone valerate and neomycin sulfate are combinations of anti-infection in skin cream. The purpose of this study was to validate intersection absorption spectrum methods and simultaneous determination of betamethasone valerate and neomycin sulfate in the skin cream using $70 \%$ ethanol as solvent. The simultaneous determination of a sample was performed with the intersection point spectrophotometric methods when betamethasone valerate and neomycin sulfate absorption spectrum were overlapped and the intersection points were obtained at wavelength $245.4 \mathrm{~nm}$. Each level of betamethasone valerate and neomycin sulfate were calculated using the regression equation. The simultaneous determination of betamethasone valerate and neomycin sulfate in cream supply obtained levels of $(107,98 \pm 1.6491) \%$ betamethasone valerate and $(94.81 \pm 2.6958) \%$ neomycin sulfate. The validation test for betamethasone valerate were as follows accuracy was $99.90 \%$, precision was $1.09 \%$, LOD was $0.645 \mu \mathrm{g} / \mathrm{mL}$, and LOQ was $2.15 \mu \mathrm{g} / \mathrm{mL}$ whereas neomycin sulfate was as follows accuracy was $99.67 \%$, precision was $1.46 \%$, LOD was $2.215 \mu \mathrm{g} / \mathrm{mL}$, and LOQ was $7.385 \mu \mathrm{g} / \mathrm{mL}$. The mixture of betamethasone valerate and neomycin sulfate used a wavelength of $245.4 \mathrm{~nm}$ as the point of intersection of the absorption spectrum and the results met Indonesian pharmacopeia requirements and this method satisfied the validation requirements.

Keywords: Betamethasone valerate, Neomycin sulfate, Validation, Intersection point, spectrophotometric
\end{abstract}

(C) RASĀYAN. All rights reserved

\section{INTRODUCTION}

The combination of Neomycin Sulfate and Betamethasone Valerate is used as a cure for topical infections due to inflamed skin. This combination is available in cream and ointment forms. Betamethasone Valerate ( $9 \alpha$-fluoro-16 $\beta$-methylprednisolone) ${ }^{1}$ is used to relieve skin irritation in a topical pharmaceutical cream $^{2}$. Neomycin Sulfate is an aminoglycoside class antibiotic that has a broad spectrum and is bactericidal by its inhibition mechanism on protein synthesis ${ }^{3}$. Betamethasone Valerate levels in a single form can be determined by spectrophotometry method. Neomycin Sulfate levels in a single form can be determined by microbiological potential measurements ${ }^{4}$. Betamethasone Valerate has maximum absorption at $240 \mathrm{~nm}\left(\mathrm{~A}^{1}{ }_{1}=390 \mathrm{a}\right)$. Neomycin Sulfate has an insignificant maximum absorption but it is present in the wavelength range $230-360 \mathrm{~nm}^{1}$. Neomycin Sulfate has a UV absorption above $200 \mathrm{~nm}$ so that it can be used as a direct detection system to carry out Neomycin Sulfate analysis in complex pharmaceutical preparations ${ }^{5}$. Various studies using spectrophotometric methods in the simultaneous determination of drug combinations have been developed by researchers including UV differential spectrophotometry ${ }^{7}$, matrix methodology ${ }^{8}$, a review on UV spectrophotometric methods ${ }^{9}$, iso-absorptive point, ratio subtraction, ratio difference and mean centering ${ }^{10}$, dual wavelength analysis and mean Rasayan J. Chem., 12(1), 232-239(2019)

http://dx.doi.org/10.31788/RJC.2019.1215013

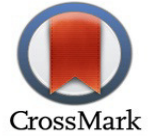


RASĀYAN J. Chem.

Vol. 12 | No. 1 |232 - 239| January - March | 2019

centering of ratio spectra $(\mathrm{MCR})^{11}$, simultaneous equation method and first-order derivative spectrophotometric $^{12}$ and another simultaneous determination methods with RP-HPLC ${ }^{13-15}$.

Simultaneous determination of Betamethasone Valerate and Neomycin Sulfate by spectrophotometry is still very limited, only one publication. Kumar, K. et al. (2016) has determined the levels of Betamethasone Valerate and Neomycin Sulfate mixtures using spectrophotometry in derivatives with methanol and water in a ratio of 6:4 (v/v) produced levels of Neomycin Sulfate and Betamethasone Valerate are $99.75 \%$ and $98.92 \%$.

The purpose of this study was to validate the intersection of absorption curve for the determination the combination of Betamethasone Valerate and Neomycin Sulfate that was measured by ultraviolet spectrophotometry.

Apparatus and Instruments

\section{EXPERIMENTAL}

UV-visible Spectrophotometer (Shimadzu 1800) and a set of Personal Computer (PC) equipped with 2.42 UV-Probe software, Minitab®17 application, $1 \mathrm{~cm}$ cuvette, glass tools (Oberol), analytical balance (Boeco Germany).

\section{Spectrophotometric Conditions}

1. Mode: Spectrum

2. Scan speed: Fast

3. Wavelength range: $400-200 \mathrm{~nm}$

4. Absorbance scale: $0.00 \mathrm{~A}-2.00 \mathrm{~A}$

5. Initial base line correction: ethanol.

\section{Chemicals and Reagents}

The raw material of Betamethasone Valerate and Neomycin Sulfate were obtained from Kimia Farma Plant Medan, Sumatera Utara, Indonesia. Betason N Cream, contained $1 \mathrm{mg}$ Betamethasone Valerate and $5 \mathrm{mg}$ Neomycin Sulfate, was a local product by PT Kimia Farma Plant Medan Indonesia. Ethanol absolute E.merck was obtained from Rudang Medan Indonesia.

\section{Preparation of Working Solution}

To prepare a standard solution of $500 \mu \mathrm{g} / \mathrm{mL}$ Betamethasone Valerate and $1000 \mu \mathrm{g} / \mathrm{mL}$ Neomycin Sulfate, each component was transferred on $100 \mathrm{~mL}$ volumetric flask. Filled the volume with $70 \%$ ethanol solvent up to the mark (standard solution), then pipetted $5 \mathrm{~mL}$ of Betamethasone Valerate standard solution and $80 \mathrm{~mL}$ Neomycin Sulfate standard solution, respectively were transferred in two different 50 $\mathrm{mL}$ and $100 \mathrm{~mL}$ volumetric flask and treated with a $70 \%$ ethanol solvent up to to get working solution having concentration $50 \mu \mathrm{g} / \mathrm{mL}$ Betamethasone Valerate and $800 \mu \mathrm{g} / \mathrm{ml}$ Neomycin Sulfate.

\section{Preparation of Maximum Absorption Spectrum of Betamethasone Valerate}

Pipetted $5.5 \mathrm{~mL}$ of working solution of Betamethasone Valerate was introduced into a $25 \mathrm{~mL}$ volumetric flask, then its volume was added using $70 \%$ ethanol solvent up to a marked line with a concentration of $11 \mu \mathrm{g} / \mathrm{mL}$, then measured its uptake at 200-400 nm wavelength.

\section{Preparation of Maximum Absorption Spectrum of Neomycin Sulfate}

Pipetted $5.3 \mathrm{~mL}$ working solution of Neomycin Sulfate was introduced into a $25 \mathrm{~mL}$ volumetric flask, then the volume was added using $70 \%$ ethanol solvent up to a marked line with a concentration of $170 \mu \mathrm{g}$ / $\mathrm{mL}$, then measured its uptake at $200-400 \mathrm{~nm}$ wavelength.

Construction Maximum Absorption Spectrum of Betamethasone Valerate and Neomycin sulfate mixture.

Pipetted a $0.8 \mathrm{~mL}$ working solution of Betamethasone Valerate and $0.9 \mathrm{~mL}$ working standard of Neomycin Sulfate into a $10 \mathrm{~mL}$ volumetric flask, then the volume was added by using an ethanol solvent up to the mark line to obtain a solution containing a mixture of Betamethasone Valerate and Neomycin Sulfate with a concentration of $4 \mu \mathrm{g} / \mathrm{mL}$ and $8.7 \mu \mathrm{g} / \mathrm{mL}$ respectively. Then made the absorption spectrum of Betamethasone Valerate and Neomycin Sulfate mixture. 
RASĀYAN J. Chem.

Vol. 12 | No. 1 |232 - 239| January - March | 2019

\section{Determine the Intersection of the Absorption Curve}

The wavelength of the intersection of the absorption curve was done by making an overlap of the Betamethasone Valerate absorption curve and the Neomycin Sulfate absorption curve so that the intersection points of the two substances were obtained.

\section{Calibration curve for Betamethasone Valerate and Neomycin Sulfate at $\mathbf{2 4 5 . 4} \mathbf{~ n m}$}

Creation of calibration curves for linearity checks as the basis for determination of the method was performed. The working solution that had a concentration in a range of $5.5-20.5 \mu \mathrm{g} / \mathrm{ml}$ of Betamethasone Valerate and $85-340 \mu \mathrm{g} / \mathrm{ml}$ of Neomycin Sulfate was prepared from the standard stock solutions of both drugs. The absorbance was measured at $245.4 \mathrm{~nm}$ and calibration curves were constructed by plotting absorbance vs. concentration ${ }^{16}$.

\section{Validation Test}

A standard solution of Betamethasone Valerate and Neomycin Sulfate was used for validating UV method at individual wavelengths as per ICH guidelines parameter ${ }^{17-20}$.

\section{Accuracy and Precision}

The determination of precision based on the relative standard deviation (RSD) value with the standard deviation requirement is relatively less than $2 \%$ and the determination of accuracy is done with the addition of a standard solution ${ }^{16-18}$.

\section{Limit of Detection (LOD) and Limit of Quantification(LOQ)}

LOD is obtained from the lowest amount that can be detected while LOQ is the lowest limit that can be measured or quantized from the studied drug with acceptable reliability ${ }^{19-20}$.

\section{Methodology}

The intersection of the absorption spectrum method could be used for the simultaneous determination of Betamethasone Valerate and Neomycin Sulfate. This research was conducted by overlapping absorption curve of $11 \mu \mathrm{g} / \mathrm{mL}$ of Betamethasone Valerate's working solution and $170 \mu \mathrm{g} / \mathrm{mL}$ Neomycin Sulfate's working solution that was measured at wavelengths between 200- $400 \mathrm{~nm}$. The intersection of the two curves was the point of intersection of the drug solution. The mixture of the two drugs and one of the wavelengths were selected to measure the total absorption of the two components of the drug using the formula below ${ }^{10}$ :

$A_{m}=A_{x 1 c m}^{1 \%} \cdot C_{m m}+C_{y 10 m}^{1 \%} \cdot C_{y m}$

$A_{m}=A_{x 1 c m}^{1 \%} \cdot\left(C_{w m}+C_{y m}\right)+C_{y 10 m}^{1 \%} \cdot C_{t m}$

Note:

$\mathrm{A}_{\mathrm{m}}$ is the absorbance of the mixture at the iso-absorptive point

$\mathrm{C}_{\mathrm{xm}}$ and $\mathrm{C}_{\mathrm{ym}}$ is the concentration of each drug in the mixture

$\mathrm{C}_{\mathrm{tm}}$ is the concentration of the mixture

After results of measured the absorption of the two components then followed by a regression equation calculation ${ }^{16}: \mathrm{Y}=\mathrm{aX}+\mathrm{b}$

\section{The Construction Sample Solution of Cream}

Weighed the content of ten tubes of cream and stirred until homogeneous then weighed $1 \mathrm{~g}$ of cream supply that was equivalent to $5 \mathrm{mg}$ of Neomycin Sulfate and transferred into a $50 \mathrm{~mL}$ volumetric flask, added $10 \mathrm{~mL}$ of absolute ethanol until dissolved and sonicated for 15 minutes using a sonicator. Then, added with $70 \%$ ethanol up to the marked line and filtered. Pipetted $7 \mathrm{~mL}$ (700 $\mu \mathrm{g}$ ) Neomycin Sulfate standard stock solution and transferred it to a $10 \mathrm{~mL}$ volumetric flask and added $1060.5 \mu \mathrm{g}$ of Neomycin Sulfate's working solution to be used as an adjunct to Neomycin Sulfate and 70\% ethanol was added to the marked line. The content of Betamethasone Valerate and Neomycin Sulfate in the sample solution was determined. 


\section{RESULTS AND DISCUSSION}

\section{Absorption Spectrum of Betamethasone Valerate and Neomycin Sulfate}

Determination of the maximum absorption spectrum was carried out at a wavelength of 200-400 nm for $11 \mu \mathrm{g} / \mathrm{mL}$ of Betamethasone Valerate's working solution and $170 \mu \mathrm{g} / \mathrm{mL}$ of Neomycin Sulfate's working solution. A cream sample was added to the working solution of Neomycin Sulfate so that the concentration of Neomycin Sulfate in the sample was proportional conditions for measuring the working solution of Neomycin Sulfate to meet the requirements of Lambert-Beer Law. The absorption spectrum of each drug and its mixture can be seen in Figs.-1, 2 and 3.
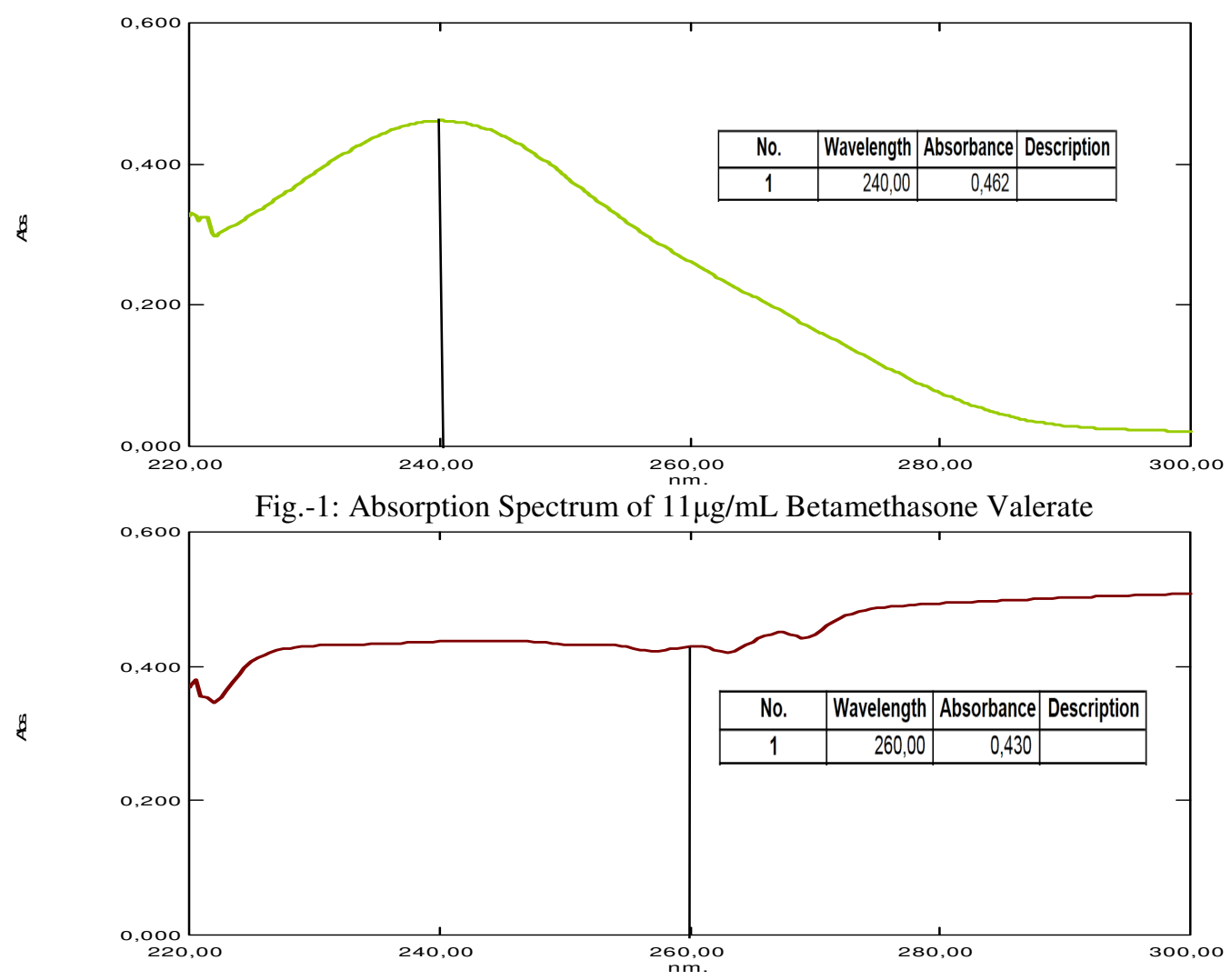

Fig.-2: Absorption Spectrum of $170 \mu \mathrm{g} / \mathrm{mL}$ Neomycin Sulfate

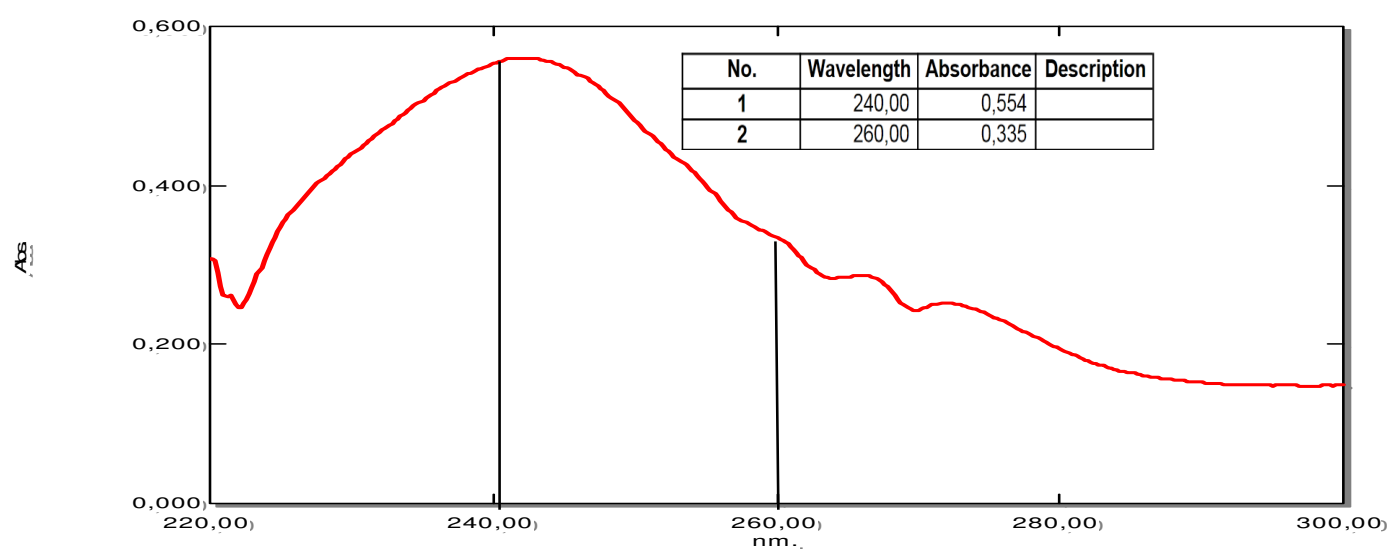

Fig.- 3: Absorption Spectrum Combination of Betamethasone Valerate and Neomycin Sulfate

Figures-1 and 2 showed that there was no difference in absorption of Neomycin Sulfate and Betamethasone Valerate in $70 \%$ ethanol with absorption in methanol. The wavelength obtained at $240 \mathrm{~nm}$ for Betamethasone Valerate and $260 \mathrm{~nm}$ for Neomycin Sulfate and these corresponded to the wavelength 
RASĀYAN J. Chem.

Vol. 12 | No. 1 |232 - 239| January - March | 2019

of absorption of these two components with methanol ${ }^{1}$. According to Moffat (2001) that Neomycin Sulfate has an insignificant absorbance from $230 \mathrm{~nm}$ to $360 \mathrm{~nm}^{1}$.

In Fig.-3 the mixture also had two maximum absorptions which were the absorption of Betamethasone Valerate and Neomycin Sulfate and both had maximum absorptions that met the Lambert-Beer Law in the area of 0.2-0.6. That means the mixture had the same absorption spectrum with each absorption spectrum in single solution form.

\section{Determination of Intersection Points}

Having obtained the maximum absorption spectrum of Betamethasone Valerate and Neomycin Sulfate at a wavelength of 200-400 nm, the two obtained curves were overlapped and gained two points of intersection of the absorption spectrum. The results can be seen in Fig.-4.

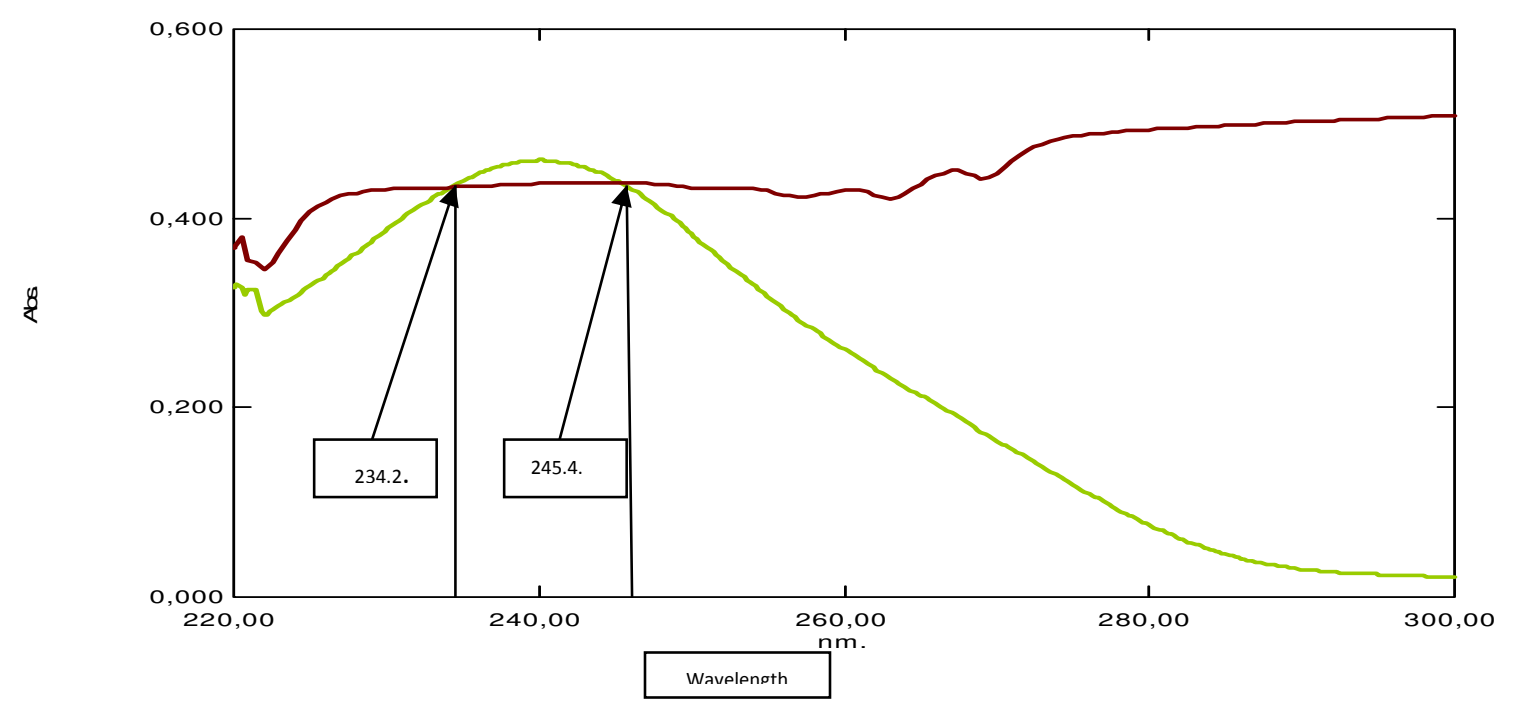

Fig.-4: Absorption spectra overlap of $11 \mu \mathrm{g} / \mathrm{ml}$ Betamethasone Valerate and $170 \mu \mathrm{g} / \mathrm{mL}$ Neomycin Sulfate

After the curves were overlapped, the overlapping absorption spectrum of Betamethasone Valerate and Neomycin Sulfate obtained at wavelengths of $234.2 \mathrm{~nm}$ and $245.4 \mathrm{~nm}$. Then the wavelength of $245.4 \mathrm{~nm}$ was used because this point is between the maximum absorption of Betamethasone Valerate at $240 \mathrm{~nm}$ and maximum absorption of Neomycin Sulfate at $260 \mathrm{~nm}$ and used to determine the content of Betamethasone Valerate and Neomycin Sulfate and expressed as an intersection absorption spectrum method.

\section{Calibration Curve}

Measurement results of Betamethasone Valerate was $\mathrm{Y}=0,04026 \mathrm{X}+0.00146$ and Neomycin Sulfate was $\mathrm{Y}=0,00254 \mathrm{X}+0.00165$ were obtained by regression equation. The calibration curve of Betamethasone Valerate and Neomycin Sulfate can be seen in Fig.-5 and Fig.-6.

The result of the calibration curve showed that there was a linear relationship between concentration and absorbance. The correlation coefficient ( $r$ ) of Betamethasone Valerate was 0.9995 and Neomycin Sulfate was 0.9999. An ideal linear relationship was achieved if the value of $b=0$ and $r=+1$. Meanwhile, the value of a indicates the sensitivity of the analysis, especially the instruments used ${ }^{18-20}$.

\section{Validation Test}

A validation test of the intersection absorption spectrum method is carried out with parameters including LOD, LOQ, accuracy and precision tests ${ }^{18}$. The result of the validation test can be seen in Table-1.

The results showed that the samples had met the requirements of LOD and LOQ. That means the concentration contained in the sample could be determined and the absorbance measurement was in the range of 0.2-0.6 so that it met the requirements of Lambert-Beer Law of LOD and LOQ. In addition, the test of the accuracy also met the validation requirements for accuracy results, which were within the range 
RASĀYAN J. Chem.

Vol. 12 | No. 1 |232 - 239| January - March | 2019

of $98 \%-102 \%^{19-20}$. According to Harmita (2004), a precision value for the analyte is not more than $2 \%^{20}$. These results indicated that the method of intersection spectral absorption met the validation requirements.

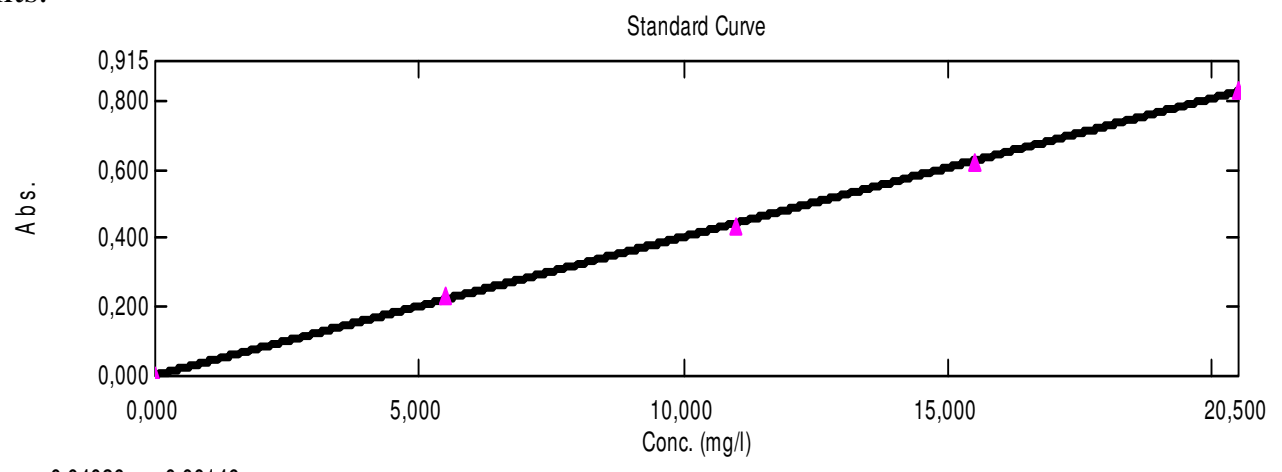

$y=0,04026 x+0,00146$

Correlation Coefficient $\mathrm{r} 2=0,99949$

Fig. -5: Calibration curve of Betamethasone Valerate

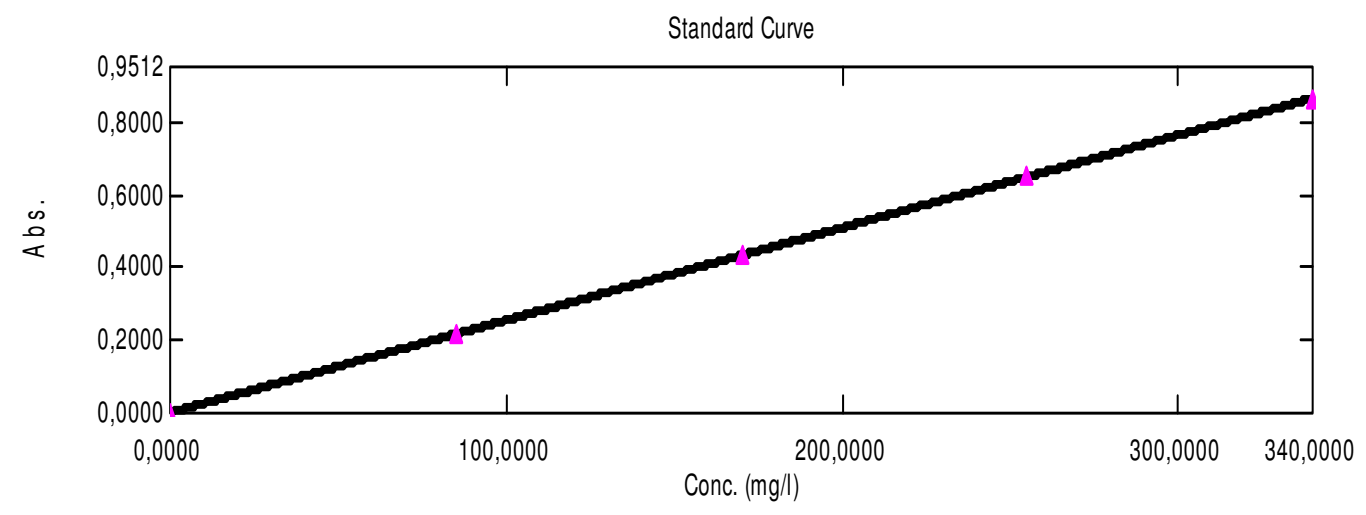

$y=0,00254 x+0,00165$

Correlation Coefficient $r 2=0,99998$

Fig.-6: Calibration curve of Neomycin Sulfate

Table-1: Result of Validation Test

\begin{tabular}{|c|c|c|c|c|c|}
\hline S. No. & Component & $\begin{array}{c}\text { LOD } \\
\mu \mathrm{g} / \mathrm{mL}\end{array}$ & $\begin{array}{c}\text { LOQ } \\
\mu \mathrm{g} / \mathrm{mL}\end{array}$ & $\begin{array}{c}\text { Accuracy } \\
\%\end{array}$ & $\begin{array}{c}\text { Precision } \\
\%\end{array}$ \\
\hline 1 & Betamethasone Valerate & 0.645 & 2.15 & 99.89 & 1.0872 \\
\hline 2 & Neomycin Sulfate & 2.215 & 7.385 & 99.68 & 1.4576 \\
\hline
\end{tabular}

\section{Determination of Betamethasone Valerate and Neomycin Sulfate Levels in Creams}

The overlap of the absorbance curves of Betamethasone Valerate and Neomycin Sulfate produced 2 intersection points at wavelengths of $234 \mathrm{~nm}$ and $245.4 \mathrm{~nm}$. The simultaneous determination of Betamethasone Valerate and Neomycin Sulfate was carried out at $245.4 \mathrm{~nm}$ wavelength by preparing a calibration curve. This intersection point was selected because it was between the maximum wavelength of Betamethasone Valerate at $240 \mathrm{~nm}$ and the maximum wavelength of Neomycin Sulfate at $260 \mathrm{~nm}$. The equation regressions for Betamethasone Valerate was at $\mathrm{Y}=0.4026 \mathrm{X}+0.00146$ and for Neomycin Sulfate was at $\mathrm{Y}=0.04039 \mathrm{X}+0.02148$. The results can be seen in Tables- 2 and 3 .

Table-2: Calculation of Betamethasone Valerate in 1 gram of cream at $245.4 \mathrm{~nm}$

\begin{tabular}{c|c|c|c|c}
\hline Replication & $\begin{array}{c}\text { Theoretical } \\
\text { weight }(\mathrm{mg})\end{array}$ & $\begin{array}{c}\text { Absorption of } \\
\text { sample }\end{array}$ & $\begin{array}{c}\text { Result weight } \\
(\mathrm{mg})\end{array}$ & Percentage levels (\%) \\
\hline 1 & 1 & 0.4441 & 1.0669 & 106.69 \\
\hline 2 & 1 & 0.4388 & 1.0863 & 108.63 \\
\hline 3 & 1 & 0.4388 & 1.0863 & 108.63 \\
\hline
\end{tabular}


RASĀYAN J. Chem.

Vol. 12 | No. 1 |232 - 239| January - March | 2019

\begin{tabular}{c|c|c|c|c}
\hline 4 & 1 & 0.4388 & 1.0863 & 108.63 \\
\hline 5 & 1 & 0.4388 & 1.0863 & 108.63 \\
\hline 6 & 1 & 0.4442 & 1.0669 & 106.69 \\
\hline \multicolumn{5}{c}{ Average } \\
\hline
\end{tabular}

Table 3: Calculation of Neomycin sulfate in 1 gram of cream at $245.4 \mathrm{~nm}$

\begin{tabular}{c|c|c|c|c|c}
\hline \multirow{2}{*}{ Replication } & $\begin{array}{c}\text { Theoretical } \\
\text { weight }(\mathrm{mg})\end{array}$ & $\begin{array}{c}\text { Absorption } \\
\text { of } \\
\text { sample }\end{array}$ & $\begin{array}{c}\text { Result } \\
\text { weight }(\mathrm{mg})\end{array}$ & $\begin{array}{c}\text { Addition } \\
\text { weight } \\
(\mathrm{mg})\end{array}$ & Percentage levels (\%) \\
\hline \multirow{2}{*}{1} & 5 & 0.3581 & 8.3333 & 3.5 & 96.67 \\
2 & 5 & 0.3513 & 8.1667 & 3.5 & 93.33 \\
\cline { 2 - 6 } 3 & 5 & 0.3569 & 8.3056 & 3.5 & 96.11 \\
\cline { 2 - 6 } 4 & 5 & 0.3513 & 8.1667 & 3.5 & 93.33 \\
\cline { 2 - 6 } 5 & 5 & 0.3569 & 8.3056 & 3.5 & 96.11 \\
\cline { 2 - 6 } 6 & 5 & 0.3513 & 8.1667 & 3.5 & $94.81 \pm 2.6958$ \\
\hline \multicolumn{7}{l}{} \\
\cline { 2 - 6 }
\end{tabular}

The average levels of Betamethasone Valerate were obtained at $(107.98 \pm 1.6491) \%$ and average level at $(94.81 \pm 2.6958) \%$ for Neomycin Sulfate. The results of statistical calculations can be seen in Table 4 .

Table-4: Statistical results combination of Betamethasone Valerate and Neomycin Sulfate in cream

\begin{tabular}{c|c}
\hline Component & Statistic percentage \\
\hline Betamethasone Valerate & $(107.98 \pm 1.6491) \%$ \\
\hline Neomycin sulfate & $(94.81 \pm 2.6958) \%$ \\
\hline
\end{tabular}

Based on Table 4, after conducting statistical tests, Betamethasone Valerate and Neomycin Sulfate levels were in the range of $90-110 \%$ which were in accordance with the requirements of the drug in the Indonesian Pharmacopoeia fourth edition in 2014. It can be said that the intersection of the absorption spectrum method can be used to assay mixture of Betamethasone Valerate and Neomycin Sulfate.

\section{CONCLUSION}

The validation of intersection absorption spectrum methods met the requirements of linearity, accuracy, precision, detection limit and quantitation limit. The statistical results proved good for simultaneous determination of Betamethasone Valerate and Neomycin Sulfate because all data obtained was accepted statistically and the levels of the two drug components met the requirements of the fourth edition of Indonesian pharmacopeia.

\section{ACKNOWLEDGMENT}

The authors wish to thank for Prof. Runtung., Rector of Universitas Sumatera Utara and Prof Erman Munir., Chairman of the USU Research Institutes in conducting research of USU Talenta 2018. This work was supported by the Universitas Sumatera Utara [grant numbers 447/UN5.2.3.1/PPM/ KPTALENTA USU. 2018].

\section{REFERENCES}

1. A. C. Moffat, M. D. Osselton and B. Widdop, Clarke's Analysis of Drugs and Poisons $4^{\text {th }}$ ed., London: Pharmaceutical Press, 973,1766 (2011).

2. Y. Xiong, K.P.Xiao, and A.B.Rustum, Journal of Pharmaceutical and Biomedical Analysis, 49(3), 646 (2009), DOI: 10.1016/j.jpba.2008.12.023.

3. S.T.Pratiwi, Pharmaceutical Microbiology, Erlangga Press, Jakarta, 88(2008).

4. The government of Indonesia, Indonesian Pharmacopoeia $5^{\text {th }}$ ed., Indonesian Health Ministry, 554,998 (2014).

5. Sudjadi and A.Rohman, Pharmaceutical Analysis, Pustaka Pelajar, Yogyakarta, 282 (2012).

6. K. K. Kiran, O. Sailaja and G. Krishnaveni, IJRRPAS, 6(1), 1381 (2016). 
RASĀYAN J. Chem.

Vol. 12 | No. 1 |232 - 239| January - March | 2019

7. S. K. Mastanamma, K. Sravani, and T.Anil, Rasayan J. Chem., 8(3), 303 (2015).

8. K. M. Madhu and C. Rambabu, Rasayan J. Chem., 10(4), 1068 (2017),DOI:10.7324/RJC.2017.1041812.

9. A.H.Kamal, S.F.El-Malla and S.F.Hammad, ejpmr, 63(2), 348 (2016).

10. H. M. Lofty, S. M.Amer, H.Zaazaa, and N.S.Mostafa, Austin J Anal Pharm Chem., 2(3), 1044 (2015).

11. S.A.Nada, A.E.Badr and I.T.Salwa, JPA, 2(3), 279 (2012), DOI:10.1016/j.jpha.2012.02.002.

12. S.K.Masimukku and R.Chintala, AJCPR, 10(4), 302 (2017), DOI:10.22159/ajpcr.2017.v10i4.16748.

13. J. Mamatha and N. Devanna, Rasayan J. Chem., 11(2), 452(2018), DOI:10.31788/RJC.2018.1122079.

14. J.Mamatha and N.Devanna, Rasayan J. Chem.,11(1), 392 (2018), DOI:10.7324/RJC.2018.1111931.

15. C.N.Nalini, P. Abhinav, N.Ramalakshmi, K.B.Kiran and K.Sahini, Rasayan J. Chem., 10(4), 1500 (2017), DOI:10.7324/RJC.2017.1041898.

16. R. A. Day and A.L Underwood, Quantitative Analysis $4^{\text {th }}$ ed., Prentice-Hall International, Englewood Cliffs, N.J., 215, 347 (1991)

17. U.S. Food and Drug Administration, Analytical Procedures and Methods Validation for Drugs and Biologics, http://www.fda.gov/ BiologicsBloodVaccines/GuidanceComplianceRegulatoryInformation/Guidances/default.htm, (2015).

18. J.Ermer and J.H.McB.Miller, Method Validation in Pharmaceutical Analysis: A Guide to Best Practice, Wiley-Vch Verlag GmBH \& Co. KgaA., Weinheim (2005).

19. A.Rohman, Pharmaceutical Chemistry Analysis $1^{\text {st }}$ ed., Pelajar Press, Yogyakarta, 224-33 (2007).

20. F.Harmita, MIK., 1(3), 118-32 (2004)

[RJC-5013/2018] 